\title{
"ZAMAN BELANDA": SONG AND THE SHATTERING OF SPEECH IN ARU, EASTERN INDONESIA
}

\section{Patricia Spyer}

This paper is about a song that was never sung to me or in my presence or, for that matter-as far as I know-sung at all during either the twenty-one months that I spent in Aru, southeast Maluku, between 1986 and 1988, or during a brief return visit there in $1994 .{ }^{1}$ Instead this song was simply presented to me by an Aruese man-as I will argue, most appropriately - written out on a white piece of paper titled with capitals at the top of the page "Zaman Belanda" or the "Dutch Era." If I had come to know this song in any other way I might have been less attuned to some of its subtleties, in particular to how the song serves as a metacommentary on the authority of songs in Aru more generally, as well as to how it speaks to the workings of songs and the histories they codify within the lives and projects of persons and collectivities in the Aru islands.

\footnotetext{
1 Twenty-four months of fieldwork in Aru $(1984,1986-88,1994)$ were funded by a Department of Education Fulbright-Hays Dissertation Fellowship, the Wenner-Gren Foundation for Anthropological Research, the Southeast Asia Council for Asian Studies with funds from the Luce Foundation, the Netherlands Foundation for Tropical Research (WOTRO), and was conducted under the sponsorship of the Lembaga Pengetahuan Indonesia and Universitas Pattimura. The Institute for Intercultural Studies provided funding for a preliminary trip to Aru in 1984 and, subsequently, for three months of archival research in the Netherlands. I am grateful to all of these institutions for their generous support of my work. The paper was presented at a conference "Time Matters" at the University of Amsterdam in November 1998 and discussed more informally by my colleagues at the Research Centre Religion and Society of the same institution. I thank especially Gerd Baumann, Birgit Meyer, Peter Pels, Henk Schulte Nordholt, Peter van Rooden, Willem van Schendel, Peter van der Veer, and an anonymous reviewer for their helpful comments and suggestions. Rafael Sánchez offered excellent advice for revision and I am grateful to him for this. Last but not least, I thank with gratitude Lakulu Kobawon for sharing with me the "Zaman Belanda" song.
} 
54 Patricia Spyer

Aru is a low-lying archipelago made up of six large central islands and multiple smaller ones clustered under the Bird's Head of New Guinea in the southeastern Moluccas. Already for several centuries, the lives of women and men in these islands have been shaped within the erratic conditions of a volatile luxury product trade, extended networks of commerce and communication, and the political projects of successive colonial and postcolonial regimes. In the eastern parts of Aru known as the archipelago's Backshore (as opposed to the western so-called Frontshore with the island capital, Dobo), relations to the economic and discursive forces of trade, the colonial mission civilisatrice, and the more recent Indonesian nation-state, have in certain important respects been incomplete and discontinuous-if at times also brutally invasive. It is this complex positioning-both entangled within and simultaneously at the margins of the nation-state-which accounts, on the one hand, for the fragmented acquaintance Aruese have with nationalist historiography, and on the other, for their ability to bend it to some of their own purposes. Relatedly, this positioning explains why Aruese refigurings of such ready-made tokens of national historiography as a distinctive "Dutch Era" betray the constrained circumstances of their production in one of Indonesia's many frontier-spaces while at the same time suggesting, once again, how people make their own history within conditions that are not of their own making.

Compared to other Aruese songs, "Zaman Belanda" is unique both in terms of its idiosyncratic structure and in the distinctiveness that it assigns to the "Dutch Era" commemorated by the song. Both idiosyncracies are addressed in this paper. The song documents the suppression of an important rebellion against colonial rule, the shattering of powerful words in this context, and the emergence of a song about the Dutch Era that, paradoxically in certain crucial respects, is the silent tomb of this event. I argue that the song marks an important depletion of Aruese authority and the emergence of a silence at the moment of its own creation. I interpret this with reference to the relative suppression of discourse about the Dutch colonial period under Suharto's former New Order and, more importantly, with respect to the song's potential political implications within the context of this especially repressive period in Indonesian history-namely, the possibility of an insurrection against the powersthat-be should potent words be allowed to circulate.

For many Barakai islanders in southeast Aru-the people with whom I spent the bulk of my time in the islands-the song is held to document an unusual if relatively unelaborated moment in Aru history-the "Zaman Belanda" or Dutch Era. What is most striking is that in contrast to the more official forms of nationalist historiography which use periodization to construct an ordered and clear chronology-and from which Barakai's "Zaman Belanda" clearly derives-locally periodization encompasses only a single period. "Zaman Belanda," in other words, stands entirely on its own, enjoying a unique position that is neither set off against or incorporated within the framework of a larger periodization. While Barakai islanders clearly recognize the concept of a "period" or "zaman" as a historiographical category, they apply this exclusively to the isolated and reified Dutch Era. In all other circumstances, any sense of periodizations or singling out of distinct eras does not apply as local historical consciousness seizes upon or inaugurates other possibilities. When women and men of Aru's Backshore speak, for instance, of the time of their own ancestors they simply invoke it with some statement along the lines of "long ago ..." Similarly, stories and 
references to the Japanese occupation of Aru tend to be casually broached with remarks like "when the Japanese were here ..." I will return to this anomaly; for the moment I highlight only some of its peculiarities.

Handed to me on a white piece of paper titled simply at the top "Zaman Belanda" and, as far as I know, never sung, the song already inscribed both the reification of a distinct Dutch era and its own silence in the manner of its presentation. The song given to me by Lakulu Kobawon, a man from the Barakai community of Longgar, one of five communities on the island, and the person who wrote down the song and titled it "Zaman Belanda," grants the particular phase of the Dutch Era registered in the song with the capacity to represent the whole. According to Lakulu, the song is about the capture by the Dutch of a member of his patriclan or fam, a man named Pukulgore Kobawon, who Lakulu claims was arrested in the 1890 s as he returned to the village after a day of diving. It is in fact quite unusual for Aruese to refer to dates, but Lakulu, unlike any other Aruese I knew on Barakai at the time, had worked in construction in the provincial capital of Ambon and was therefore somewhat more attuned than other islanders to national discourses. During his stay in Ambon, he may have internalized some aspects of nationalist historiography such as its chronologies since these were embedded within the organization of public space throughout New Order Indonesia, in the aesthetics and form given by this regime to its official monuments, as well as more explicitly in the curriculum of its national education system. ${ }^{2}$

In referring to the 1890 s as the time of a rebellion which might have involved one of his ancestors, Lakulu was not far off the mark. In 1892, a large-scale revolt involving Barakai Islanders and many other Backshore peoples swept the eastern and southeastern pearldiving areas of the archipelago. The movement was only suppressed when Dutch battle ships were brought in, several armed confrontations had taken place with some loss of life on the Aruese side, three villages were reduced to ashes, and the rebellion's most important leaders had been turned over to the colonial authorities. Beginning in the 1850s in northeast Aru and then with mounting frequency between the early 1880 s and the first decade of the twentieth century, the archipelago's Backshore peoples who subsisted primarily from the seasonal collection of various "splendid and trifling" luxury articles for trade-mother-of-pearlshell, trepang, birds of paradise, edible birds' nests ${ }^{3}$-rebelled periodically against what colonial sources tend to gloss as "Buginese and Makassarese" or "Chinese" traders and their "extortionist practices" (Dutch, knevelarijen). ${ }^{4}$ The majority of the Dutch accounts downplay any resistance to their own rule, choosing to highlight instead as the primary causes of the disturbances either the exploitative practices that they associated especially with the Muslim traders-in particular the credit system through

2 Timothy C. Lindsey, "Concrete Ideology: Taste, Tradition, and the Javanese Past in New Order Public Space," in Culture and Society in New Order Indonesia, ed. Virginia Matheson Hooker (Oxford: Oxford University Press, 1995), pp. 166-182.

3 J. C. van Leur, Indonesian Trade and Society (The Hague: W. van Hoeve, Ltd., 1955).

${ }^{4}$ H. C. van Eijbergen, "Verslag eener reis naar de Aroe- en Key Eilanden in de maand Junij, 1862," Tijdschrift voor Indischen Taal-, Land-en Volkenkunde 14 (1866): 223, 239. See also G. W. W. C. Baron van Hoëvell, "De Aroe-Eilanden, Geographisch, Ethnographisch en Commercieel," Tijdschrift voor Taal-, Landen Volkenkunde 32 (1890): 38. 
56 Patricia Spyer

which they indebted Aruese men and women to themselves-or the superstitious nature of the indigenous population.

Following the interpretations of the colonizers, the superstition of the local peoples allegedly made them highly susceptible to the influence of charismatic and-from the Dutch perspective-somewhat crazed persons who were recognized as the leaders of the rebellions. In colonial sources the terminology used to describe such persons often placed them within the realm of the resolutely irrational. Thus, such leaders appear as geestdrijver (fanatic), woelgeest (agitator), onruststoker (firebrand), belhamel (ringleader) or, in the more journalistically flamboyant terminology used by the head correspondent of an Indies paper, as hoofdboekanier (head buccaneer. $)^{5}$ Occasionally, Aruese superstition could allegedly be turned to the advantage of the colonizers as in the context of the first of the rebellions of the 1880s and 1890s that took place in central Aru in 1881. By chance the Dutch resident happened to arrive in Aru when the rebellion was already underway. According to one source, the resident managed to restore peace and order simply by dispatching to the Aruese leader of the rebellion, Belbel, an ancestor statue wrapped in cloth that had been obtained in a neighboring south Moluccan island. Accompanied by the message that the "iene" statue would stand as witness to any further disruption of the peace, this messenger allegedly sufficed to stop the revolt against the colonial government. ${ }^{6}$

Although the rebellions of 1882, 1885-87, and 1907 mark especially fraught moments in the complex entanglements and mutual adjustments in Aru of colonialism and trade, commercial relations in the islands and especially on the archipelago's Backshore, were frequently unsettled by strife and violence. Along with the regular tensions that appear to have accompanied trading in Aru, repeated mention is made in nineteenth-century sources of conflicts among Aruese over access to sites of collection, between these collectors and the traders over debt payments, ${ }^{8}$ and of accusations by Aruese men of the traders' mistreatment of their women and other abuses. ${ }^{9}$

What the Dutch sources consistently fail to note, however, is that the rebellions of the 1880 s and 1890 s coincided with the expansion and consolidation of colonial rule in the islands as suggested, for instance, by the appointment of two postholders to Aru in 1882 (though, admittedly, this decision may have itself been triggered by the 1881 rebellion). Perhaps even more strikingly, no mention is made of the pearling companies from Banda and Australia which began to operate in the seas off of Aru's

5 "Fanatic" found in "De expeditie naar de Aroe-eilanden," Indische Gids 15,1 (1893): 862-72. "Agitator" and "firebrand" found in "Hoe men in 1881 een woelgeest op de Aroe-eilanden tot rede bracht," Indische Gids 15,2 (1893): 1247-49. "Ringleader" and "head buccaneer" found in Koloniaal Verslag (The Hague: Algemeene Landsdrukkerij, 1893).

6 "Hoe men in 1881 een woelgeest op de Aroe-eilanden tot rede bracht," p. 1249.

${ }^{7}$ Mailrapport 1880, 6392\# 128+. See also van Hoëvell, "De Aroe-Eilanden, Geographisch, Ethnographisch en Commercieel," p. 25.

8 P. Bleeker, Reis door de Minahassa en de Moluksche Archipel in 1855, 2 vols. (Batavia: Lange \& Co., 1856), p. 92. See also van Eijbergen, "Verslag eener reis naar de Aroe- en Key Eilanden in de maand Junij, 1862," p. 239.

${ }^{9}$ J. F. G. Brumond, "Aanteekeningen gehouden op eene reis in het oosterlijk gedeelte van den Indischen Archipel," Tijdschrift voor Nederlandsch-Indië 7,2 (1853): 78, 293. J. B. J. van Doren, Fragmenten uit de Reizen in den Indischen Archipel, Part I (Amsterdam: J. D. Sybrandi, 1854), pp. 385-6. 
Backshore in this same time period. The sources that I consulted suggest that the companies frequently trespassed in the areas where Aruese customarily dove and may in other respects have disrupted the regular, if often volatile, commercial relations that the local population seasonally engaged in with their more usual trading partners. In the mid-1880s Sech Said Baadilla, the lieutenant of the Arab community in Banda, received permission to dive for pearl oysters off of Aru's Backshore and around the same time Australians also began to fish in this area. In 1893, or a year after the rebellion involving Barakai Islanders broke out, the colonial government published an ordinance punishing diving by outsiders in Aru's territorial waters-reckoned as three English sea miles from the coast which were reserved for the local population's own habitual collection of oysters, mother of pearlshell, and trepang..$^{10}$ It is clear that at times Backshore communities received some sort of retribution from these companies for fishing in their territory, and I was told on Barakai of some large "manila" gongs which in this context had been given to several communities as a payment. ${ }^{11}$ Since, however, two warships were regularly dispatched to keep the peace on the Backshore during the diving season and a colonial source directly attributes the placement of a controleur in the archipelago capital, Dobo, in 1903 to the repeated conflicts between Aruese and the pearling companies, it is doubtful how forthcoming or effective such retribution really was. ${ }^{12}$

While acknowledging that tensions must have already existed between Aruese and their regular trade partners, we can conclude that the rebellions of the late nineteenth and early twentieth centuries clearly emerged in the context of the consolidation of Dutch rule in the islands as merely the local version of a much larger process of imperial expansion that was taking place throughout the Netherlands East Indies at this time. Equally importantly, the movements also surfaced within a complex situation which must have involved the reshuffling of Backshore trade dynamics due to the novel pressures and competition that were introduced with the arrival of the Bandanese and Australian pearling companies. While the differences and details having to do with the successive rebellions are difficult to glean from the sources, what is clear is the great extent to which all of these were thoroughly wrapped up in the workings of trade in the archipelago. Thus, while the most violent and extreme of the movements, that of 1892 , called for the banishing of all trade from Aru, along with banishment of the Dutch colonizers, as the precondition for a mass return of dead ancestors to the islands, other rebellions more mildly envisioned the exile of only a handful of trade's main representatives or the rectification by the colonial authorities of some of the most egregious of the latter's abuses. ${ }^{13}$

10 A. J. Beversluis and A. H. C. Gieben, Het Gouvernement der Molukken (Weltevreden: Landsdrukkerij, 1929), p. 190. See also H. van Kol, Uit onze koloniën. Uitvoerig reisverhaal (Leiden: A. W. Sijthoff, 1903), p. 223.

11 The crews of the loggers were usually Japanese or "Manilans" in addition to some south sea islanders. See Beversluis and Gieben, Het Gouvernement der Molukken, p. 195. Merton who visited Aru in 1908 mentions the captain of a logger-who was also the diver and in addition to the tender and five sailors formed the crew-from the Fiji Islands. See Hugo Merton, Forschungsreise in den Südostlichen Molukken (Aru- und Kei Inseln) (Frankfurt A. M.: Senckenbergischen Naturforschenden Gesellschaft, 1910), p. 145.

12 Beversluis and Gieben, Het Gouvernement der Molukken.

13 Mailrapport 1893, 6499 \#38+, December 5, 1892 from Resident van Hoëvell to the Governor General of the Netherlands East Indies. 
58 Patricia Spyer

Of all the movements that swept the Backshore in the late nineteenth century, that of 1892 seems to have been both the largest and the most violent. The Colonial Report (Koloniaal Verslag) of 1893 contains a fairly detailed synopsis of the rebellion which began in late September/early October of 1892 on the archipelago's Backshore or at "that time approximately when the Chinese and Makassarese merchants of Dobo and other Frontshore communities customarily come to trade."14 According to the report, twenty-three Chinese and Makassarese, including women and children, who had arrived to the Backshore at the beginning of the commercial season were killed while others were noted as missing. Although the Colonial Report fails to specify the location of the killings, a report from the Commander of Amboina and Ternate makes it clear that the rebellion began in the important pearldiving community of Krei on Trangan Island to the immediate west of Barakai, an area which also provided one of the movement's main leaders, a man named Toelfoeloen. ${ }^{15} \mathrm{~A}$ prior report of December 5 , 1892, sent by the Resident of Amboina, van Hoëvell, to the Governor General of the Netherlands East Indies, confirms the central role that was also played by the pearldiving communities of Barakai Island in the rebellion. What is more, a court case held on Barakai in June of 1893 compensates twenty-seven traders representing all five communities on this island for damage to their houses and wares as a result of the rebellion. ${ }^{16}$ I quote at length from van Hoëvell's report as it provides a sense of the scale and severity of the resistance waged by Backshore Aruese against the Dutch colonizers and the traders. It also serves as an illustration of the Dutch insistence on both the extortionist practices of the traders and the superstition of the archipelago's population.

My initial idea that the movement, as has more often been the case in Aru, would have been solely directed at the foreign traders, who perhaps would have provoked it due to their extortions, appears not to be correct, and it became clear to me that there was opposition as well to the Netherlands Indies Government, as indicated by the upside-down display of the Dutch flag on their prahus [boats], by the casting away by Barakai headmen of their staffs of office [Dutch rottingknoppen], and by the tearing up of their acts of appointment. A certain inhabitant of Krei named Toelfoeloen, a man already up in years and a former pearl diver, has set himself up as a fanatic [Dutch, geestdrijver] after having spent some time in isolation. He claims to have had consultations with the sun on several occasions and to be called upon to restore the old heathen religion to all of Aru, also to the frontshore (where as is already known there are many Christians and Mohamedans). He says that if his orders are followed then through his prayers all of the dead will come back to life and that without the

14 Koloniaal Verslag, pp. 25-28.

15 Mailrapport 1893, 6499 \#69+ .January 10, 1893.

16 Quite a number of the names are Chinese while the title Daen (properly Daeng) before proper names indicates a Buginese origin. One name, Abdul Salam, is properly Arabic while a few others like "Honey" (Madoe) and "Rat" (Tikoes) are presumably nicknames. According to the report the traders due to receive compensation included nine resident in Apara (Abdul Salam, Langale, Batjo Kalankarie, Daen Pawara, Ingtai, Palalo, Manloeka, Moesa, Tamalaga), eight in Longgar (Tan Kwan Tjai, Oei Hie Hoan, Seng Tjoan, Daen Baoe, Madoe, Wa Kasso, Daoeda, Sempo), seven in Bemun (Daen Paliwan, Tonga Patola, Salewa, Tikoes, Palarie, Wanalisa, Batjo), one in Mesiang (Daen Mangesa), and two in Gomo-gomo (The Thie, Daen Matola). See Mailrapport 1893: 6503, \#858+, ARA. 
help of foreigners they will receive from heaven everything that they require. For the Government or better the Company no one need fear since he will take care to dry up the sea as soon as war ships approach the villages. In a very short time he has acquired a large following and it can be said that the entire backshore, with the exception of Lola and Mariri (who have not yet forgotten their chastisement of 1887 ) is already part of the movement. ${ }^{17}$

On November 24, a little more than a week before this report was sent to the Governor General, a fleet of eighty-five native prahus each carrying fifteen to twenty men armed with krisses (probably machetes), bows and arrows, and spears launched an attack on Aru's capital Dobo. The attack was repelled by fifteen well-manned Makassarese vessels which had come to trade in the islands, as these were also supported by the regents of several Christian communities near the capital. By this time, according to a message sent by the Dobo postholder to Amboina, "all trade stood still" in the islands, the Makassarese and Chinese having fled to the capital from the Backshore, leaving the bulk of their tradewares behind. Only a day after the attack, on November 25, a detachment of forty men landed in Dobo along with twelve prisoners (Dutch, kettinggangers). It was, however, not until a good month later, when two battle-ready steamships, the Java and the Arend, arrived at Aru, that the colonial government could begin the work of "chastisement" of the Backshore communities and of those leaders regarded as the main instigators of the rebellion. Along with Krei on Trangan, two villages in northeast Aru in the Batulay area were burned to the ground while others were visited by the battleships and their headmen and populations severely reprimanded.

On March 27, 1893 the Commander of the Java, Jansan van Afferdens, sent a telegram to the Commander of the Navy in Batavia in which he reported the "complete submission" of the rebellious villages which at this time surrendered the main leaders of the rebellion and a large portion of the stolen goods to the colonial authorities. ${ }^{18}$ Presiding over the surrender himself, the Resident of Amboina, van Hoëvell " . . . pointed out to the headmen that this was by now the third time that to their own detriment they had listened to just anyone wanting to profit from their credulity, in 1882 to Belbel, in 1887 to Naelaer and now again, and worst of all, to Toelfoeloen." 19 The six leaders handed over to the authorities are mentioned both in Jansan van Afferdens' telegram and in the 1893 Colonial Report. They were: Toelfoeloen of Krei whom the Dutch saw as the rebellion's main instigator; Wainaka of Watoelei (Batulay) described as the second head of the revolt and said to have himself killed a number of Chinese traders; Djerman, orang kaya of Watoelei; Goerier, orang tua of Affara [Apara] who is also referred to as "the second head of Affara" (the first head or majoor of this Barakai village Apara having died of wounds suffered in the attack on Dobo); Marwai, the representative of Toelfoeloen; and Bairoki, who commanded the fleet of

\footnotetext{
${ }^{17}$ Mailrapport 1893, $6499 \# 38+$. All translations from Dutch or Barakai, the Austronesian language spoken by the approximately 2,500 inhabitants of the island of the same name, are my own.

18 Mailrapport 1893, 6501 \# 455+ to Commander of the Navy in Batavia from Commander "Java" Jansan van Afferdens, Afschrift Telegram, April 6, 1893.

${ }^{19}$ Mailrapport 1893, $6501 \# 497$ + to Governor General of N.I. from Resident van Hoëvell, April 1, 1893.
} 
eighty-five prahus in the attempted attack on Dobo. ${ }^{20}$ All of these men were arrested and taken on board the steamship to be imprisoned in Ambon.

My knowledge about these rebellions emerged over several years and in bits and pieces. On my first trip to Aru in 1984 I was shown a cannonball in the Backshore pearldiving village of Kumul in the Batulay area of northeast Aru which was offered as "proof" of this community's own history of resistance against the former colonizers. Only some three years later, however, during archival work in the Netherlands, I also learned that Kumul had been one of the three villages destroyed by the Dutch in early 1893. An inkling of Barakai's own involvement in the rebellion began in 1986 as dawn rose after an all night house-raising in the Barakai village of Longgar and talk among members of the Kobawon fam with whom I was staying turned to what Backshore Aruese subsume under the rubric of sejara, a cognate of the Indonesian word for "history" or sejarah, about which I will have more to say later. It was in this setting that Pukulgore Kobawon's name first came up, and as I was given an overview of the particular "history" (Barakai, sejara) with which he is associated on Barakai, several of this man's descendants wept. Although at the time it was pointed out to me that this history had its song (Barakai, ai ken $s a b$ ) it was only later that the song was presented to me, as I have said, by Lakulu on a white piece of paper titled "Zaman Belanda."

This presentation occurred when I returned to Barakai Island in July of 1987 after a six month break imposed by national elections in Indonesia. Part of my time away from Aru had been spent in various archives in the Netherlands where, as already mentioned, I came across the sources on the late-nineteenth century rebellions which I draw upon in the above discussion. I also found some early photographs of Aru in the collection of the Royal Institute of Linguistics and Anthropology (Koninklijk Instituut voor Taal-, Land-en Volkenkunde, henceforth KITLV) in Leiden which I brought back with me to Barakai, including one photo from the album of a colonial official who had visited the islands around the turn of the century, apparently in the context of the 1892 rebellion. According to the hand-written caption on the back of the photograph depicting six Aruese men-four in loincloths wearing various kinds of beadwork and bracelets and two in jackets and trousers" -it showed the "Heads of the Rebellion in the Aru Islands. Died in Prison in Ambon, circa 1890" (Hoofden van de Opstand van de Aroe Eilanden. Gestorven in de gevangenis op Ambon, circa 1890).

${ }^{20}$ Orang kaya, orang tua, and majoor are all indigenous rank titles. In Aru an orang kaya ranked higher than an orang tua as is also clear from the Dutch description of the orang tua of Affara [sic] as this village's second head. A majoor was commonly an assistant of a headman. For an informative discussion of the historical use of such titles in the Moluccas and along the West Papuan coast see Roy Ellen, "Conundrums about Panjandrums: On the Use of Titles in the Relations of Political Subordination in the Moluccas and Along the Papuan Coast," Indonesia 41 (1986): 47-62.

21 Both Lakulu and Belwi Kobawon claimed that the Aruese men in trousers and black jackets came from villages that were Christianized in the late nineteenth century. Thus, the man on the left, they said, came from Ngaibor, the first Protestant village on the Backshore, on the island of Trangan. Conversely, the man on the right was from one of the villages near Dobo - either Wangel or Durjella-which were actually Christianized much earlier in the seventeenth century. The vast majority of Aru's Backshore pagans did not convert to a world religion until 1976-77 when they were forced to by local bureaucrats as a prerequisite to participating in the national elections of 1977. See Patricia Spyer, "Serial Conversion / Conversion to Seriality: Religion, State, and Number in Aru, eastern Indonesia, " in Conversion to Modernities: The Globalization of Christianity, ed. Peter van der Veer (New York: Routledge, 1996), pp. 171-98. 
Lakulu, other members of the Kobawon fam, and a few other islanders singled out the same man as the leader Pukulgore, and they did so not only because of his baldness, which runs in the fam, but even more because of the manner in which the man they identified as their kinsman in the photograph wears his loincloth-wrapped three times around his hips-and because of the large bracelet he boasts on his left arm. The unusual wrapping of the loincloth and the bracelet, which Lakulu said was of solid gold, were taken as "signs" or "proofs" by which the leader could be identified. By claiming that the massive bracelet was made of gold, Lakulu already conjured the powers through which on Barakai his ancestor could only have obtained such a valuable object.

According to Lakulu, the reason motivating Pukulgore's arrest by the Dutch also explains why the names of the leaders of the rebellion had not been recorded by the colonizers either on the back of the photograph or in the album in the KITLV collection. ${ }^{22}$ It was Pukulgore's powerful speech, itself at least in part attributable to the possession by this Longgar headman of $i l m u$, or specialized knowledge, that caused his arrest. ${ }^{23}$ When both Lakulu and Belwi Kobawon, a granddaughter of the leader, spoke attributing $i l m u$ to their kinsman, this special knowledge appeared unburdened by the usual connotations of illegitimacy and covertness with which it is commonly identified on Barakai. In the photograph the presence of such "black magic" is betrayed only by the gold bracelet adorning the leader's arm, while beyond this, Pukulgore's possession of powerful ilmu can also be inferred in the momentous effects and transformations in the world that his descendants and other islanders claimed were set in motion whenever he spoke. According to Lakulu, the effects of Pukulgore's powerful speech not only explained why the Dutch arrested him but also why they immediately silenced him when they did. In so doing, Lakulu explained, the colonizers acted in part on the advice of the Buginese traders who were active on Barakai Island at the time and who presumably therefore already had first-hand experience of the effects of Pukulgore's words, words, indeed, so powerful that if one credits van Hoëvell's report they were at least in the case of Toelfoeloen capable of summoning the very dead back to Aru in support of their descendants' rebellion. In forbidding Pukulgore and the other Aruese leaders of the rebellion to speak, however, this meant that even their names were never voiced. This is why, following Lakulu, none of the leaders' names was recorded on the back of the archival photograph since they were simply not spoken.

A finely textured interweaving of silence and sound, the "Zaman Belanda" song stages the violent interruption of powerful Aru speech by the colonial authorities-a "breaking off" of "words spoken"-against the backdrop of a soundscape of dazzling complexity. Not only does the song's own composition occur silently "in the head" of a pearl diver named Jamin - thereby already prefiguring the silence that will be

\footnotetext{
22 At the time, I had not yet connected the Colonial Report of 1893, which does mention six men who were arrested, with the six men in the photograph with which I returned to Barakai. It is possible that the "second head of Apara" mentioned in the 1893 report might have actually been from Longgar since the two communities are adjacent and physically shade into each other.

${ }^{23}$ Pukulgore is said to have spoken Malay in addition to the Barakai language. Not surprisingly, given the long and extensive history of trade in this area, many Aruese in fact spoke some Malay. But Pukulgore is said to have been especially fluent, having worked as a boy selling rice and fried cakes made from sticky rice (lapa-lapa) to Buginese traders.
} 
imposed by the Dutch with the arrest of the Barakai leader-but as a text it also conjures a shifting chorus of more embodied versus more distant and displaced voices. Complicating any absolute contrast between the notion of an arrested/silenced subject versus that of an authorized speaker, the song gives expression to a range of potential applications and identifications with sejara by historically positioned persons. Demonstrating once again that there is no clear-cut answer to the question "can a subaltern speak?," 24 "Zaman Belanda" gives empirical substantiation to the theoretical proposition that speakers are neither unified entities nor their words transparent expressions of subjective experience. ${ }^{25}$

The "Zaman Belanda" song does not detail the events comprising the rebellion nor does it name the motivations behind it. The song focuses not on the rebellion as such but rather on the moment of its suppression, which is also the moment of the song's own composition. Besides the story of the song's emergence, it also tells of the arrest of an important leader, of his incarceration on board a warship, and of a meeting between the Dutch colonial authorities, the Buginese traders, and some Aruese headmen. Significantly, the song situates the moment of its own creation directly in the context of pearldiving. Before presenting the song I first give an overview of each stanza based on Lakulu's own exegesis of "Zaman Belanda." The first stanza tells of the song's composition out on the diving grounds by a man named Jamin, whom Lakulu claimed was the father of the young diver Daldal. Because an important decision is about to be made in Longgar regarding the recent rebellion, the man dives in haste. Already in this first stanza, "Zaman Belanda" discloses the outcome of the decision that is about to be made in Longgar: the song anticipates, as in a future past, the violent interruption or "breaking off" of this village's powerful speech. Notably, the song is not sung but rather silently composed in Jamin's head. In this way, the song's very composition is itself metaphoric of that which it (silently) speaks-the shattering of powerful Aru speech and its confinement to a "Zaman Belanda" past-as well as perhaps of its own future status as a text inscribed on a piece of paper, handed to the anthropologist, and (presumably) never sung.

In the second stanza as the leader Pukulgore begins to speak two Ambonese soldiers immediately blow their whistles to silence him. If the future past formulation of the song's first stanza frames from the very start the Dutch Era as completed and closed, such closure is forcefully enacted in the second stanza as a radical break between a time of powerful speech, on the one hand, and a politically imposed silence, on the other. Thus, most importantly, the "breaking off" of the village's powerful speech, announced as an impending event in the first stanza, is practically fulfilled in the second stanza when colonial representatives cut off Pukulgore's speech-"the leader speaks, he utters, two Ambonese blow whistles." Also in the second stanza, the Longgarese leader is led to the colonizers' ship while the headmen of Barakai, seated in chairs and armed with their colonial staffs of office, confront angry Buginese in a meeting convened by the Dutch between the islanders and these traders. Assigned in the first stanza to the past, the powerful speech of the leader makes way in the second

24 Gayatri C. Spivak, "Can the Subaltern Speak?" in Marxism and the Interpretation of Culture, ed. Cary Nelson and Lawrence Grossberg (Urbana, IL: University of Illinois Press, 1988), pp. 271-313.

25 Webb Keane, "Voice," in "Lexicon for the New Millenium," Special Issue of Journal of Linguistic Anthropology, ed. Alessandro Duranti (forthcoming), p. 2 of Keane manuscript. 
stanza for an "exchange of words" between former enemies as orchestrated and mediated by a third party, the Dutch colonial authorities. The completion of a "Zaman Belanda" as a period closed in upon itself is further announced by the colonial staffs of office, broken and tossed away in the context of the rebellion, but now wielded by Barakai headmen as the privileged tokens of their proper place within a larger colonial scheme. ${ }^{26}$

The song's third stanza homes in on the arrested leader-arrested we are told "because of words spoken" against the colonial authorities-as he is escorted to the battleship by his grandson Sirgwa. While being led away, Pukulgore hushes his daughter Magar, thereby perhaps generalizing his own silencing by the Dutch to other Aruese. In the very next line, however, the voice of the arrested leader who boards the ship to be taken away to Ambon comes to the fore in the first person: "I climb up ... I see two young Ambonese women sleeping." Especially enigmatic in this third stanza is an observation attributed by Lakulu to his ancestor who glances at the vessel's bridge and notices that "the writing has changed." Lakulu suggested that the writing referred to the name of the battleship and that therefore the ship that conveyed Pukulgore to Ambon must have been different from the ones that more commonly stopped at Barakai. What, in any event, this line does is to allocate the "scene of writing," and by extension the historiography of Aru or of an inscribed "Zaman Belanda" handed to the anthropologist, irrevocably to the realm of an external other. At the same time, however, if the external other puts in an appearance here in the form of writing, so too, side by side with this, does the voice of Pukulgore, saved and preserved in the Dutch Era song for, presumably, many, many years. In the third stanza, a shift occurs from the more neutral reporting of the first and second stanzas to the first person of the third stanza which is also the speech of the arrested Barakai leader.

In the fourth and last stanza an Aruese subject is addressed as "you go to the beach at Dobo." This subject is pressed into service by the song and, by extension, by sejara, as the spectator of an Ambonese commander who himself peers through his eyeglass at the arrested Longgarese leader who, in turn, is laughing a great laugh. As in the third stanza, where the preserved first-person voice of the leader only emerges on board the colonial ship-and thus is also framed by the scene of writing assigned to an external other-so too, does the laugh of the great man appear suspended and held within the gaze of an Ambonese commander's eyeglass. Yet the leader's voice has been preserved for future generations in the Dutch Era song, just as his laugh is not only caught in the colonial eyeglass but also seen by other Aruese from the vantage of Dobo's beach. If in this overview I have gone on at some length, it has been precisely to map out some of these ambiguities and undecidabilities, and to show how, stanza by stanza, the song reveals and refracts an array of potential subject positions and relatively authorized, muted, and displaced voices as these are variously framed, foreclosed, preserved, and opened up in order to, presumably, leave "Zaman Belanda"'s further workings out to future generations of speaking and singing Aruese.

${ }^{26}$ Patricia Spyer, "The Tooth of Time, or Taking a Look at the 'Look' of Clothing in Late NineteenthCentury Aru," in Border Fetishisms: Material Objects in Unstable Spaces, ed. Patricia Spyer (New York: Routledge, 1998), pp. 162-3. 
64 Patricia Spyer

Here then is my English translation of the Maluku Malay translation that Lakulu and I wrote of the Barakai song. I follow Lakulu's division of the song into four parts. The song goes as follows:

1. Rasuk darnomnom kol-kol sien

dal tamenmen ru dam da eti

gwagwil malala Daldal

Jamin asis em Logar sel

Logar selo

dam sabe a gul

asis wanu el rau

A fleet of sailing boats dives off of the white beach

they drift on their anchors 27

a young man Daldal dives pressed for time

[his father] Jamin says:

it will be decided in Longgar

in the village of Longgar

he began to compose in his head the song [about the affair]

that would break off the village's powerful speech

2. Gulne lirauo, lirnal

Ambong rua dajo ngol-ngol

gulne a ta

Gul daririn tan kader

tongko Walad

Bugis nal goggora

Walad asis em mairun

kom guguli dajur Bugis

dam derwa rau

The leader speaks, he utters

two Ambonese blow whistles

the leader [is led] to the sea

the headmen rest sitting in chairs

[they have] Dutch colonial staffs of office

the Buginese are angry

the Dutch decide that today

our headmen and the Buginese

will exchange words

27 Following Lakulu, this line and the following indicate that the divers are in a hurry since the news of the Dutch arrival in Longgar to arrest their headman, Pukulgore Kobawon, had already reached them. Instead of moving to another location and casting out their anchor again, they let their lines out and drift on their anchors. 
3. Sirgwa jamlir muwe mi kabal

Magur amam nam lelerwi

kiolar malala wuwun

kutmat kabal ken manara

tuliso ruba lei

korkojamor kabal wun

kuliskol reson lau-lau

kawolko gulala murin

kutmat rarar Ambong rua denden

Because of words spoken Sirgwa you escort him to the ship

the father hushes Magar

I climb up

I glance at the ship's bridge

the writing has changed

I ascend to the top of the ship

I climb up the ship's ladder

I go into the back of the cabin

I see two young Ambonese women sleeping

4. Ja murbano Lob koljurun

kabalio aulen lau

Ambong dua limnal gorgornean

eslal nal Logar dua

evjin melmel

You go to the beach at Dobo

a ship is at sea

the Ambonese commander raises his eyeglass

he scans and spots the Longgarese leader

who is laughing a great laugh.

This song differs in a number of important respects from other songs sung by Barakai women and men that are held to bear testimony to and even to be saturated with "history" or sejara. Unlike any other song that I know of, this one documents the moment of its own creation, a moment of silence in which a song that is itself composed without being sung announces the violent interruption of powerful Aruese words. Quite striking is that everything happens as if the song's composition and, therewith, the emergence of sejara actually anticipates the shattering of powerful speech, or, in other words, that as modes of communication sejara and powerful speech are somehow antithetical. Yet, if the names and voices of Barakai islanders and their leaders are, following Lakulu, silenced, this attempt at imposing silence itself has a name: it is called "Zaman Belanda" or the Dutch Era, and it marks a break between the past of sejara and the present, which at the time I was handed the song by Lakulu was still that of Suharto's New Order regime.

If we wish to understand the anomaly of the "Zaman Belanda" song, a brief discussion of the interrelationships between songs and sejara on Barakai more generally is first necessary. Songs that can be brought to bear on sejara are classified locally as "proofs" (Barakai ken bukti) due to their ability to serve as a material witness to a 


\section{Patricia Spyer}

given "history" with which the song is held to be entangled and to commemoratesuch as, for instance, the above song does with respect to the "Zaman Belanda."28 Hence the off-hand comment on the night of the house-raising in Longgar when I was first told of Pukulgore's sejara: " . . it has its song" (Barakai, ai ken sab). In its capacity both to act as a witness and to codify a particular repertoire of sentiments associated with a given sejara, a "proof" - whether in the form of a song, a special object such as a colonial staff of office (Dutch, rottingknop), or a feature of Barakai's natural sceneryhas an objectified, thing-like character. In the hands of a skilled storyteller who rallies the various "proofs" that, familiar to her audience, texture and imbue her tale with the appropriate authority and sentiment, a given sejara acquires a certain objectivity. Sejara, a cognate of the Indonesian word for "history," sejarah, should therefore be understood not only as designating a "history" but also as the very referent about which a history is told-not only, then, discourse, but also the discoursed world.

Just as histories told on Barakai seem to have a certain permanence through their embeddedness in things which have "always been there, from a very long time ago," so too do songs have a certain permanence by being articulated in a linguistic register that stands somewhat apart from that of the everyday..$^{29}$ Because of the predominance in many songs of archaic constructions and even unintelligible foreign words, they often seem to participate in the very histories which their singing by islanders recalls. Beyond what were seen as such obvious signs of age, the widespread distribution throughout the Backshore of a well-known repertoire of songs sung on occasions like marriage, which bring large numbers of people from different places together, may also contribute to this general perception of songs as antique and unchanging. At such gatherings songs are remembered and sung with the various parties and persons present first usually running through a gamut of the more widely shared and codified songs and then, as the night wears on and drinking loosens tongues and spirits, newer compositions will sometimes take shape. Yet even the most innovative of such newly formed songs will necessarily have a somewhat familiar ring to them for Backshore listeners and therefore remain, to a greater or lesser degree, suffused with a sense of sejara. Built up as they usually are out of short, already codified song "tips" (Barakai, sab ken toh), "trunks" (Barakai, sab ken un $)^{30}$ and a lesser marked middle, they are flung as offerings into the common pool of smoke, alcohol, and recollection by the most prominent of a night's singers or proposed from the sidelines by lesser-voiced younger men and, to some extent, women. These songs, consequently, almost always comprise one or more stanzas already known to some people or that at least sound as if they should be.

28 Patricia Spyer, The Memory of Trade: Modernity's Entanglements on an Eastern Indonesian Island (Durham, NC: Duke University Press, 2000). See also Janet Hoskins, The Play of Time: Kodi Perspectives on Calendars, History, and Exchange (Berkeley: University of California Press, 1993), p. 120, and Webb Keane, Signs of Recognition: Powers and Hazards of Representation in an Indonesian Society (Berkeley: University of California Press, 1997).

29 Webb Keane, "Knowing One's Place: National Language and the Idea of the Local in Eastern Indonesia," Cultural Anthropology 12,1 (1997): 41.

30 On "tips" and "trunks" elsewhere in Indonesia see James J. Fox, "Sister's Child as Plant: Metaphor in an Idiom of Consanguinity," in Rethinking Kinship and Marriage, ed. R. Needham (London: Tavistock Publications, 1971), pp. 219-52; James J. Fox, The Flow of Life: Essays on Eastern Indonesia (Cambridge: Harvard University Press, 1980); Elizabeth Traube, Cosmology and Social Life: Ritual Exchange among the Mambai of East Timor (Chicago: Chicago University Press, 1986). 
Besides the general silence apparently surrounding and imbuing the "Zaman Belanda" song, another striking aspect of the song is its idiosyncratic division into four parts. As the above overview of songs on Barakai suggests, songs commonly consist of three as opposed to four parts-namely, a trunk, a tip, and an unmarked or lesser marked middle. The ordering of songs from "trunk" to "tip" evokes their inherent futurity and the inbuilt capacity of songs to expand beyond themselves by generating distinct but related forms of narrative discourse. This particular understanding of songs is what allows them to be deployed in the projects of Barakai women and menin discursive relation to other narrative forms-as an authorizing source for their different actions, assertions, and endeavors.

The "Zaman Belanda" song with its unique four-part structure seems to foreclose the capacity inherent in other Barakai songs to "grow," as it were, and expand beyond themselves. Rather than futurity and growth, the four-part structure identified by Lakulu with the "Zaman Belanda" song suggests the kind of completeness that on Barakai is associated with things fourfold and that, in my experience, was not granted to other songs on the island. The expression "to take four" (dai kau), for instance, often heard in ritual settings, means to encompass all four wind directions and in so doing to trace out a complete circle, thereby effecting the appearance of a certain closure and completion. In contrast to the futurity and open-endedness inbuilt in other songs, the only future which the "Zaman Belanda" song anticipates is the shattering of powerful Barakai words of resistance to the Dutch colonizers coincident with the song's own creation. What is arguably at issue here is not a sejara which in its very structure intimates its possible applications in the projects of persons and collectivities but rather a signpost or a border marker constituting a break between a distinct closed-off Dutch Era and a present social order with respect to which the short-circuited sejara of a "Zaman Belanda" could have no relevance or bearing. As the song itself suggests, it documents not in the first instance the potency or possibilities of sejara-or if so, only obliquely-but instead the radical suppression of powerful words.

Notably, the only point in the "Zaman Belanda" song when a potential Barakai singer comes to embody the sejara which the song commemorates-which, if you recall, shifts speaker position several times-or the only point where the action spoken of in the song occurs in the first person is when the Longgar leader has already been silenced-his voice, name, and body arrested-and he boards the Dutch warship to be taken to Ambon where he is said to have died in prison ("I climb up, I climb to the top of the ship," etc.). The "I" of the song which is the " $\mathrm{I}$ " of the resistance against an oppressive colonial situation and the " $\mathrm{I}$ " of "Zaman Belanda" appears therefore as a confined and silenced " $\mathrm{I}$ " or as an arrested speaker in the full sense of that formulation. What complicates this reading, however, and subverts the colonial imposition of a complete silence is Pukulgore's great laugh as-crucially-the very last sound-image of the song. Rather than colonial success, Pukulgore's laugh bursting out even as the Longgarese leader is caught and held in the Ambonese commander's eyeglass seems to signal its opposite-the inevitable inability of the colonial state or, for that matter, its postcolonial successors totally to impose silence on their subjects.

Given, however, that Pukulgore's laugh is in the first place seen and not heard and that the designation "great" belongs to an arrested leader whose powerful speech has been violently broken off by oppressive colonizers, its meaning should not be taken as 


\section{Patricia Spyer}

self-evident. A simple interpretation of "native resistance" along the lines of say, "he who laughs last, laughs loudest" would entirely bypass the subtle shifts in voice and the panoply of possible subject positions that, as I suggested above, "Zaman Belanda" invites us to consider. I prefer therefore to leave open the status of the laugh and the question of what kind of intentionality the song ascribes or does not ascribe to Pukulgore as a historical subject. Less spectacular than any confirmation of "resistance," what I believe the leader's laugh intimates is how subjectivity can never be fully caught or stabilized and necessarily remains in excess of the many attempts to contain it. In the case of "Zaman Belanda," however, excess does not come readymade, inbuilt organically, as it were, into the song's very structure, as is the case I argue with respect to other Barakai songs which commonly index their own possible futures in a movement from "trunk" to "tip" to beyond. Closed off and turned in upon itself, the excess of "Zaman Belanda" can only erupt at the interstices, so to speak, that emerge in the song in the very shifting among subject positions and the moves it makes in and out of disparate voices.

Beyond such possibilities, which can only be gleaned obliquely, what can be said with more certainty about the song is that, while hedged in many ways by silence, it is also the site where a residue of Pukulgore's powerful speech has been preserved, albeit as the politically contained voice of a colonial prisoner recording the very moment of its arrest. Although framed by the space-time of a "Zaman Belanda," the song's preservation of the leader's voice potentially enables identifications with this Barakai big man and, perhaps even more, with the kind of powerful speech for which he is most remembered on the island. During my entire time in Aru, however, as far as I know and for reasons that I will consider shortly, this did not happen. As a song that codifies the shattering of words and the interruption of powerful discourse at a particular historical moment, a song which was presented to me during another era of marked repression and censorship in Indonesia, it was therefore perhaps only fitting that "Zaman Belanda" came to me in a manner that foregrounded more its silence than its potential: already written, already codified as sejara, on a white piece of paper and at the time at least apparently linked to no particular project-except perhaps my own.

Having called attention to some of the idiosyncrasies of the "Zaman Belanda" song, I can now venture an explanation as to why this song is so unlike any other that I encountered in Aru. Recall the extent to which both the concept of sejara and that of a "Zaman Belanda" are inflected by the national historiographic discourse that was characteristic under Suharto, so that even in such a frontier-space of the nation-state as Aru such terms can still be said to bear some traces of this wider state provenance. Let us look therefore first to this historiography to see if it offers anything which might help account for the anomaly of Aru's "Dutch Era" and its documentation of a violent colonial act of silencing.

In a remarkable paper on "Memory Work and Colonial Studies: Recasting the Colonial in Contemporary Java," Stoler and Strassler record their initial surprise at the reluctance and evasiveness of many Javanese to speak about the Dutch colonial past. As opposed to the "safe," highly codified public discourse on the Japanese occupation with its reiterated themes of suffering and sacrifice, accounts and memories of the "three hundred years of Dutch rule" emerged with difficulty in a marginalized and 
fraught discursive terrain. ${ }^{31}$ Beyond the officially codified "three hundred" or "three hundred and fifty" years of colonial oppression, there seemed to be no easily recoverable or even available memory sites or fragmented rememberings among those Javanese subalterns who one might have thought would have been those persons most likely to preserve more intimate recollections of the former colonizers-namely, those women and men who had worked as servants in Dutch colonial homes. This "thinness of public discourse about colonial oppression," notable during the New Order, stands in stark opposition to the relative "thickness" of references to colonial oppression during the Sukarno period. ${ }^{32}$ According to Stoler and Strassler, such anti-imperialist sentiments evoked for the Suharto regime the "extreme" leftism of the Sukarno period and were also regarded as likely to inhibit foreign investment and tourism. ${ }^{33}$ More importantly, however, what these authors-invoking Pemberton ${ }^{34}$-quite rightly single out as the overriding factor accounting for the relative silencing that surrounded the colonial period under Suharto is what they describe as "the New Order state's own eerie resemblance to it." 35

The emphases, "blind spots," and repressions of the nationalist historiography characteristic of the Suharto period reached Aru's Backshore complexly through diverse channels-through the national language, Bahasa Indonesia, and the country's educational system, through government and church officials who visited the archipelago's eastern pearldiving areas, through traders resident on the island, as well as through the national media, both radio and only very recently, in the mid-1990s, through national television. These kinds of influences are, of course, difficult to track. What seems plausible, however, is that the relative marginalization of "Zaman Belanda" in the former New Order's official historiography has indeed left a mark on Barakai's own Dutch Era song.

Be this as it may, under the political conditions of the former New Order the song's theme would have already justified its careful hedging by silence or the shortcircuiting of the futurity that is otherwise commonly built into the very structure of Barakai songs. What is more, the song's theme further explains why the " $I$ " of the song only emerges as the signifier of a subject under arrest who, at first glance at least, appears wholly confined and silenced. This theme is, of course, that of a displaced insurrection and of the political effects which may be brought about should powerful speech be released and allowed to circulate. Everything that has happened in Indonesia since the downfall of Suharto in May of 1998 suggests, indeed, how the circulation of powerful words like reformasi or of rumors can trigger dramatic social and political change as well as extreme violence. But in the late 1980s, when I was handed the "Zaman Belanda" song on a white piece of paper, the possibility of the kind of political action, aspirations, and upheaval that we have witnessed recently in Indonesia or of an end to the New Order seemed extremely remote. For this reason, back then, the power that

31 Ann Laura Stoler and Karen Strassler, "Memory Work and Colonial Studies: Recasting the Colonial in Contemporary Java," pp. 11-12. Paper presented at the Research Centre Religion \& Society, April 1998.

32 Ibid.

33 Ibid.

34 John Pemberton, On the Subject of "Java" (Ithaca, NY: Cornell University Press, 1994).

${ }^{35}$ Stoler and Strassler, "Memory Work and Colonial Studies: Recasting the Colonial in Contemporary Java." 
70 Patricia Spyer

Barakai islanders commonly attributed to sejara could-when it came to the "Zaman Belanda" song-not be accessed in the usual manner. In contrast to other songs sung as "proofs" to authorize the deployment of sejara in different situations, the colonial history commemorated in the "Zaman Belanda" song could, following Lakulu, only be tapped at the grave of his ancestor and, crucially, only by engaging in ilmu-invoked here by Lakulu with the full illicit force ilmu commonly enjoys on Barakai as "black magic." It is this exclusive mediation by ilmu of Pukulgore's formidable powers that betrays how calling up the sejara of the insurrection against colonial authority was felt to be tainted with illegitimacy and a politically suspect act under New Order conditions.

The relative silence in New Order historiography on the Dutch Era, foreclosing any easy comparison between that past and the recent oppressive Suharto present, and, even more importantly, the mobilization of persons against the powers-that-be by "words spoken," suggest why a radical split appears to sever the words of the past from the violently imposed silence of the New Order. A period unto itself, "Zaman Belanda" stands as a signpost between powerful Aru leaders like Pukulgore, with their ability to sway entire populations, on the one hand, and the political illegitimacy of alternative visions, voices, and authorities under Suharto's hard-handed rule, on the other. Under present conditions, when throughout Indonesia powerful words are once again being spoken and where, among other places, in Maluku violence is rampant, one can only hope that those voices emphasizing openness and the non-destructive assertion of difference will prevail. 